\title{
IMPLEMENTASI METODE AL-MIFTAH LIL ULUM DALAM PEMBELAJARAN KITAB KUNING DI PONDOK PESANTREN SIDOGIRI PASURUAN
}

\author{
Choirul Mala Muzaky \\ Email: cakzaky@gmail.com \\ Madrasah Aliyah Syekh Tambuh Pasirian Lumajang, Indonesia \\ Nurhafid Ishari \\ E-mail: hafid@iaisyarifuddin.ac.id \\ Institut Agama Islam Syarifuddin Lumajang, Indonesia
}

\begin{abstract}
Abstrak: Kitab kuning merupakan literatur pembelajaran yang menjadi khas pesantren, akan tetapi dalam mempelajari literatur tersebut membutuhkan pemahaman dari gramatika Arabnya. Metode al-Miftah Lil Ulum dapat mengantarkan para santri yang baru mengenal dunia pesantren untuk dapat lebih cepat dalam memahami kaidah-kaidah nahwu dengan mudah. Artikel penelitian ini menggunakan pendekatan kualitatif deskritif dengan pendekatan studi kasus. Kesimpulan penelitian ini membutuhkan banyak persiapan. Karenanya membutuhkan strategi untuk mencapai tujuan dimaksud. Untuk mencapai impact yang diharapkan berkenaan dengan pemahaman gramatika bahasa Arab, dibutuhkan persiapan-persiapan teknis dalam proses pembelajaran, antara lain guru harus diberikan pembinaan sebelum proses KBM, dan bagi santri diberikan tes dan pembinaan belajar tulisan pego arab. Beriutnya, dalam proses pelaksanaannya yang menggunakan sistem modul 4 jilid al-Miftah, para santri diwajibkan untuk menghafal nadzam yang ada dalam al-Miftah. Dari hasil implementasi yang dilakukan, dalam waktu yang relatif singkat santri dapat membaca kitab gundulan (tanpa harakat dan tanpa makna) beserta dengan tarkib (susunan) serta dalilnya (dasar-dasarnya).
\end{abstract}

Kata Kunci: Metode al-Miftah Lil Ulum, Pembelajaran kitab kuning

\section{Pendahuluan}

Pondok pesantren merupakan lembaga pendidikan Islam tertua dan berakar cukup kuat di tengah-tengah masyarakat. Selain itu, pesantren memiliki keunikan tersendiri yang berbeda dari lembaga pendidikan lain du tanah air. Salah satunya ialah sistem nilai yang dikembangkan sejak berpuluh-puluh tahun lamanya dan tetap eksis hingga sekarang. ${ }^{1}$

Pesantren sebagai lembaga pendidikan tradisional islam yang sangat berperan dalam dimensi masyarakat tentu harus menyeimbangkan diri dengan perkembangan zaman. Maka dengan demikian, pesantren tidak hanya sebagai institusi lembaga pendidikan juga harus mengembangkan dirinya sesuai dengan perkembangan zaman. Untuk itu pesantren juga mengembangkan metode-metode dalam pembelajarannya guna meningkatkan kualitas penyaluran ilmu yang lebih berkualitas. ${ }^{2}$

Kitab kuning merupakan identitas yang inheren dengan pesantren. Istilah kitab kuning sebenarnya dilekatkan pada kitab- kitab warisan abad pertengahan Islam

\footnotetext{
${ }^{1}$ Abu Yazid, dkk, Paradigma Baru Pesantren Menuju Pendidikan Islam Transformatif (Yogyakarta : IRCiSoD, 2018), 13

2 Mastuhu, Dinamika Sistem Pendidikan Pesantren : Suatu Kajian Tentang Unsur Dan Nilai Sistem Pendidikan Pesantren, 62 
yang masih digunakan pesantren hingga kini. Kitab kuning identik dengan tulisan yang berbahasa arab dan biasanya tidak dilengkapi dengan harakat. ${ }^{3}$

Pembelajaran kitab kuning merupakan suatu wahana untuk menyalurkan dan mengkaji karya para ulama dan cendikia muslim yang dilakukan oleh pesantren sebagai upaya untuk mendidik santri sebagai penerus generasi Islam di bidang pendidikan maupun moral.

Persoalan yang paling krusial dalam memahami kitab kuning adalah menyangkut penguasaan bahasa Arab. Bagaimanapun bahasa arab dipesantren merupakan bahasa primer didasarkan karena hampir seluruh refrensi yang digelutinya menggunakan bahasa arab sebagai mediumnya. Dalam tradisi pesantren, kurikulum pengajaran bahasa Arab diberikan dengan topang sedikitnya dua disiplin pendukungnya, diantaranya Nahwu dan Sharaf. Dua disiplin inilah yang menjadi pintu masuk bagi para santri untuk mendalami literatur-literatur yang ada sekaligus menuangkan secara produktif dalam wujud karya-karya tertulis, misalnya kitab AlAjrumiyyah, Imrithy, Mutammimah, dan Nazdom Al-Maqsud merupakan kitab yang dipelajari ditingkat dasar dan menengah, sedangkan kitab Alfiyah 'Ibn Malik dipelajari ditingkat atas.

Ironisnya, pembelajaran kitab kuning sering kali masih menjadi persoalan karena tradisi proses belajar menggajar masih terbiasa dengan budaya oral dan tulisan, hal ini diakaibatkan karena metode pengajarannya yang kurang terstruktur dan tertata secara sistematis.

Pembelajaran kitab kuning merupakan suatu wahana untuk menyalurkan dan mengkaji karya para ulama dan cendikia muslim yang dilakukan oleh pesantren sebagai upaya untuk mendidik santri sebagai penerus generasi Islam di bidang pendidikan maupun moral.

Di zaman yang serba instan dan cepat ini, Sidogiri juga menemukan sebuah solusi dalam mengatasi metode lama yang dianggap kurang instan bagi kalangan muda zaman now. Saat ini pondok pesantren Sidogiri menerapkan metode cepat baca kitab kuning yang dinamakan dengan metode Al-Miftah Lil Ulum yang disusun oleh bagian dewan kurikulum pesantren dengan nama metode Al-Miftah Lil Ulum untuk mempermudah santri baru dalam membaca dan memahami kitab kuning.

Yang menarik dari metode ini adalah dalam jangka waktu yang relatif singkat (dalam waktu 100 hari), murid/santri sudah dapat membaca kitab kuning gundulan beserta dengan gramatika arabnya. ${ }^{4}$

Metode yang digunakan dalam penelitian ini adalah kualitatif. Sedangkan pendekatan dan jenis penelitian yang digunakan adalah pendekatan studi kasus yang merupakan pendekatan kualitatif yang penelitianya mengeksplorasikan kehidupan nyata, sistem terbatas kontemporer

\footnotetext{
${ }^{3}$ Zamakhsyari Dhofier, Tradisi Pesantren, 55

${ }^{4}$ Pengurus PP Sidogiri, Tamasya, 87
} 
(kasus) melalui pengumpulan data yang detail dan mendalam yang melibatkan beragam sumber informasi dan melaporkannya dalam bentuk deskripsi. ${ }^{5}$

\section{Pesantren dan Metode Baca Kitab Kuning}

Pembelajaran adalah suatu kombinasi yang tersusun meliputi unsur-unsur manusiawi, material, fasilitas, perlengkapan dan prosedur yang saling mempengaruhi untuk mencapai tujuan pembelajaran.

Usaha pembelajaran ada hubungannya dengan belajar yang dihayati oleh seorang pembelajar (siswa), yang dilakukan oleh pembelajar (guru). Pada satu sisi, belajar yang dialami oleh pembelajar terkait dengan pertumbuhan jasmani yang siap berkembang. Pada sisi lain, kegiatan belajar yang juga berupa perkembangan mental tersebut juga didorong oleh tindak pendidikan atau pembelajaran. Dari segi guru, kegiatan belajar siswa merupakan akibat dari tindak mendidik atau kegiatan mengajar. Proses hasil belajar sebagai dampak pembelajaran. Ditinjau dari acara pembelajaran, maka dampak pembelajaran tersebut sejalan dengan tujuan pembelajaran. ${ }^{6}$

Kitab kuning sering disebut dengan istilah kitab klasik (Al kutub Al-qadimah), kitab-kitab tersebut merujuk pada karya-karya tradisional ulama klasik dengan gaya bahasa Arab yang berbeda dengan buku modern. ${ }^{7}$ Ada juga yang mengartikan bahwa dinamakan kitab kuning karena ditulis diatas kertas yang berwarna kuning. ${ }^{8}$ Jadi, kalau sebuah kitab ditulis dengan kertas puth, maka akan disebut kitab putih, bukan kitab kuning.

Kitab kuning menurut Azyumardi Azra adalah kitab-kitab keagamaan berbahasa Arab, Melayu, Jawa atau bahasa-bahasa lokal lain di Indonesia dengan menggunakan aksara Arab, yang selain ditulis oleh ulama di Timur Tengah, juga ditulis oleh ulama Indonesia sendiri. Pengertian ini, demikian menurut Azra, merupakan perluasan dari terminologi kitab kuning yang berkembang selama ini, yaitu kitab-kitab keagamaan berbahasa Arab, menggunakan aksara Arab, yang dihasilkan oleh para ulama dan pemikir Muslim lainnya di masa lampau khususnya yang berasal dari Timur Tengah.

\footnotetext{
${ }^{5}$ John W. Creswell, Penelilitian Kualitatif \&Desain Riset, terj. Ahmad Lintang Lazuardi, 145

${ }^{6}$ Dimyati dan Mudjiono, Belajar dan Pembelajaran, (Jakarta: Rineka Cipta, 1999), 38

${ }^{7}$ Ending Turmudi, Perselingkuhan Kiai dan Kekuasaan, (Yogyakarta: Lkis, 2004), 62.

${ }^{8}$ Ahmad Barizi, Pendidikan Intregratif: Akar Tradisi \& Intregasi Keilmuan Pendidikan Islam. (Malang: UIN Maliki Press, 2011), 62

${ }^{9}$ Azyumardi Barizi, Pendidikan Islam: Tradisi dan Modernisasi Milenium Baru, (Jakaarta: PT. Logos Wacana Ilmu, 1999), 111.

24 | Tarbiyatuna: Jurnal Pendidikan Islam; Volume 13, Nomor 1, Februari 2020 
Pondok pesantren merupakan dua istilah yang menunjukkan satu pengertian. Pesantren menurut pengertian dasarnya adalah tempat belajar para santri, ${ }^{10}$ sedangkan pondok berarti rumah atau tempat tinggal sederhana terbuat dari bambu. Di samping itu kata pondok mungkin berasal dari bahasa Arab funduq (فندوق) yang berarti penginapan. ${ }^{11}$ Di Jawa termasuk Sunda dan Madura umumnya digunakan istilah pondok dan pesantren, sedang di Aceh dikenal dengan istilah dayah atau rangkang atau nuansa, sedangkan di Minangkabau disebut surau. ${ }^{12}$

Sedangkan pondok pesantren menurut Mujammil Qomar yang menukil dari M. Arifin adalah suatu lembaga pendidikan agama Islam yang tumbuh serta diakui masyarakat sekitar, dengan sistem asrama (komplek) dimana santri-santri menerima pendidikan agama melalui sistem pengajian atau madrasah yang sepenuhnya berada di bawah kedaulatan dari leader ship seorang atau independen dalam segala hal ${ }^{13}$

Departemen RI memberikan pengertian pondok pesantren dengan mengacu pada ciri-ciri pondok pesantren. Pondok pesantren mempunyai setidaknya 5 ciri-ciri yang terdapat pada suatu lembaga pondok pesantren, yaitu kyai, santri, pengajian, asrama dan masjid/mushola dengan aktivitasnya. Sehingga dengan kelima unsur tersebut dapatlah dibuat suatu pengertian pondok pesantren. ${ }^{14}$

Ke-5 ciri yang dikemukakan oleh departemen RI tersebut senada dengan yang diungkapkan oleh Zhamaksyari Dhofier menuturkan lima elemen dasar dalam pondok pesantren adalah pondok, masjid, santri, pengajaran kitab islam klasik dan kyai. Dengan kelima elemen tersebut barulah suatu lembaga dapat dikatakan sebagai pondok pesantren. ${ }^{15}$

Pengertian metode Al-Miftah Lil Ulum terdiri dari kata metode dan Al-Miftah Lil Ulum yang merupakan sebuah nama yang diambil dari buku Al-Miftah Lil Ulum yang dikeluarkan oleh Batartama. Kata "metode" secara etimologi berasal dari bahasa Yunani yaitu "methodos". Kata ini terdiri dari dua suku kata, yaitu "metha" yang berarti melalui atau melewati, dan "bodos" yang berarti jalan atau cara. Maka metode memiliki arti suatu jalan yang dilalui untuk mencapai suatu tujuan. ${ }^{16}$

\footnotetext{
${ }_{10}$ Abuddin Nata, Inovasi Pendidikan Islam, (Jakarta, Salemba Diniyah, 2016), 67

11 Zamakhsyari Dhofier, Tradisi Pesantren,(Jakarta: LP3ES, 2015), 41

${ }_{12}$ Nurcholis Madji, Bilik-Bilik Pesantren Sebuah Potret Perjalanan, (Jakarta: Paramadina, 1997), 4

${ }^{13}$ Mujamil Qomar, 2

14 Departemen Agama RI, Pola Pengembangan Pondok Pesantren, (Departemen Agama: Ditpekapontren Ditjen Kelembagaan Agama Islam, 2003), 24

15 Zamakhsyari Dhofier, Tradisi Pesantren,(Jakarta: LP3ES, 2015), 79

${ }^{16}$ Ismail, Strategi Pembelajaran Agama Islam Berbasis Paikem, (Semarang: Rasail, 2008), 7
} 
Sedangkan menurut kamus besar bahasa Indonesia adalah cara teratur yang digunakan untuk melaksanakan suatu pekerjaan agar tercapai sesuai dengan yang dikehendaki. ${ }^{17}$

Dengan demikian dapat disimpulkan bahwa metode merupakan suatu cara untuk mencapai suatu tujuan. Allah SWT. sendiri telah mengajarkan kepada manusia supaya mementingkan metode. Sebagaimana Kalamullah pada surat An-Nahl ayat 125:

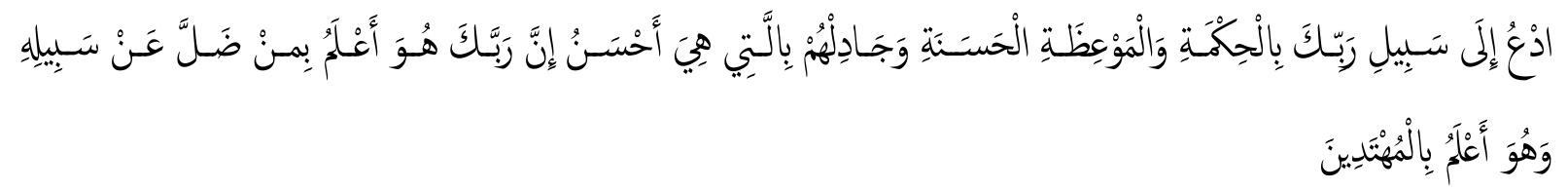

Artinya: "Serulab (manusia) kepada jalan Tuban-mu dengan bikmah dan pelajaran yang baik dan bantablah mereka dengan cara yang baik. Sesunggubnya Tubanmu Dialah yang lebih mengetahui tentang siapa yang tersesat dari jalan-Nya dan Dialah yang lebih mengetabui orang-orang yang mendapat petunjuk"

Ayat tersebut merupakan seruan kepada manusia untuk menyampaikan ajaran Tuhan dengan cara-cara yang bijaksana sesuai antara bahan dan orang yang akan menerimanya dengan mempergunakan faktor-faktor yang akan dapat membantu suapaya ajarannya itu dapat diterima. ${ }^{18}$

Sedangkan Al-Miftah Lil Ulum adalah nama dari sebuah metode cepat membaca kitab kuning bagi santri usia dini yang disusun oleh Batartama (Badan tarbiyah madrasah, yaitu instansi yang menangani kurikulum pendidikan di Pondok Pesantren Sidogiri) yang berisikan kaidah Nahwu dan Sharraf untuk tingkat dasar. Hampir keseluruhan isi Al-Miftah Lil Ulum disadur dari kitab Jurmiyah dan ditambah beberapa keterangan dari Alfiyah Ibn Al-Malik dan Nadzm Al-Imrity. Istilah yang digunakan dalam materi ini hampir sama dengan kitab-kitab nahwu yang banyak digunakan di pesantren. Jadi, metode ini sama sekali tidak merubah istilah-istilah dalam ilmu nahwu. ${ }^{19}$

Sebagai metode cepat membaca kitab kuning bagi anak-anak, Al-Miftah Lil Ulum disetting agar mudah dipahami oleh anak usia dini. Mulai dari Bahasa Indonesia yang mudah dipahami, kesimpulan dan rumusan yang sederhana, serta dilengkapi dengan tabel, skema, dan beberapa model latihan, hingga kombinasi dengan lagu-lagu yang cocok untuk usia anak-anak. ${ }^{20}$

\footnotetext{
17 W.J.S poerwadarminta, Kamus Besar Bahasa Indonesia, (Jakarta: Balai Pustaka, 1994), 652

18 Muhammad Bin Alwy, Mafabim Yajibu An Tushohbah (Surabaya: Ma'had Ad-Diinii As-Salafy), 73

19 Pondok Pesantren Sidogiri, Mari Kembalikan Gairah Baca Kitab di Bumi Nusantara Bersama Al-Miftah Lil Ulum, (sidogiri.net diakses pada tanggal 20 Pebruari 2018 pukul 01.23)

${ }^{20}$ Ahmad, dkk, Efektivitas Penerapan Metode Al-Miftah Dalam Meningkatkan Kemampuan Membaca Kitab Kuning Bagi Santri Baru Di Pondok Pesantren Syaichona Moh. Cholil Bangkalan Madura (Jurnal Pendidikan dan Pranata Islam, 2017), 40.
}

26 | Tarbiyatuna: Jurnal Pendidikan Islam; Volume 13, Nomor 1, Februari 2020 p-ISSN: 2085-6539; e-ISSN: 2242-4579 


\section{Sejarah dan Perkembangan Metode Al-Miftah Lil Ulum}

Di mulai pada tahun 2010 pendidikan di Sidogiri mengalami kemunduran khususnya dalam bidang baca kitab kuning yang tentunya berdampak pada pelajaranpelajaran yang lain dan otomatis mempengaruhi nilai hasil ujian. Hal ini menuntut Batartama untuk berpikir keras mengatasi permasalahan tersebut. Hingga kemudian ada instruksi langsung dari majelis keluarga untuk tanggap dan sigap menangani permasalahan ini.

Melihat situasi tersebut, Batartama dengan cepat membuat konsep dasar materi kurikulum dan sistem pendidikan baru yang sasarannya adalah santri dan murid baru hingga terciptalah metode Al-Miftah Lil Ulum dengan motto "mudah membaca kitab kuning".

Pada awal-awal percobaan metode ini dibatasi hanya sekitar 500 peserta yang semuanya adalah santri baru. Dari ke-500 peserta tersebut ada sekitar 350 yang berhasil menguasai kitab Fath Al-Qorib (sebuah kitab yang dijadikan tolok-ukur dalam metode ini) .

Keberhasilan metode $\mathrm{Al}$ - Miftah Lil Ulum ini bisa dianggap begitu pesat. Dari pertama kali diterapkannya metode ini sampai sekarang (sekitar 5 tahun) sudah berhasil mewisuda sebanyak 2000 santri dalam kategori baca. Dan 50 santri kategori hafal, bahkan ada 70 lembaga yang sudah menerapkan metode ini. ${ }^{21}$

\section{Garis-garis Besar Metode Al-Miftah Lil Ulum}

Yang dimaksud garis-garis besar metode Al-Miftah adalah pola pikiran dan penggunaan secara global sebagai ciri khas dari metode tersebut agar dijadikan dasar dan pelaksanaannya. Adapun garis-garis besar metode Al-Miftah adalah:

1. Kitab Al-Miftah terdiri dari 4 jilid Nadhom danTashrif.

2. Buku metode Al-Miftah diprioritaskan bagi santri baru yang sudah bisa membaca dan menulis Arab pego.

3. Setiap santri hendaklah mempunyai buku metode Al-Miftah untuk belajar.

4. Waktu pelaksaan KBM yang mencapai 4 jam (3 jam pagi sampai siang, dan 1 jam di waktu malam).

5. Setiap kelas tidak lebih dari 15 peserta. $^{22}$

\section{Kelebihan dan Kekurangan Metode Al-Miftah Lil Ulum}

${ }^{21}$ Ahmad, dkk, Efektivitas Penerapan, 40-41.

22 Ahmad, dkk, Efeketivitas Penerapan, 41. 
1. Singkat dan Praktis

Disampaikan dengan bahasa yang sangat singkat dan praktis. Kandungan isinya hanya mengambil poin-poin paling penting di dalam membaca kitab dan membuang poin yang tidak perlu atau bersifat pendalaman.

2. Desain warna

Didesain dengan tampilan dan kombinasi warna agar tidak membosankan dan cocok untuk anak-anak, Karena menurut penelitian, belajar dengan menggunakan warna lebih efektif untuk anak-anak dari pada hanya sekedar hitam putih.

3. Lagu dan skema

Untuk memancing otak kanan maka metode ini dilengkapi dengan skema dan lagu yang sudah familiar di telinga anak-anak sepertil lagu"balon ku ada lima" yang dijadikan lagu "Isim-isim yang lima". Hasilnya sangat mudah sekali untuk bagi anak memahami dan menghafal materi Al-Miftah ini.

4. Ciri-ciri (Rumus)

Di antara yang membedakan dengan metode baca kitab pada umumnya adalah metode Al-Miftah ini dilengkapi dengan ciri-ciri kedudukan yang sering dijumpai dalam susunan bahasa Arab, sehingga dengan ciri-ciri tersebut anak bisa membaca kitab sekalipun belum tahu arti dan pemahamannya.

Selain kelebihan, Al-Miftah juga mempunyai kekurangan. Di antaranya:

1. Materi yang diajarkan hanyalah materi inti dari nahwu-sharaf, sehingga peserta didik masih membutuhkan terhadap kaidah-kaidah tambahan dalam pemantapan membaca kitab.

2. Bagi santri yang sudah pernah belajar nahwu-sharaf akan merasa kejenuhan karena setiap materi harus ada pengulangan.

3. Bagi santri yang sudah dewasa akan merasa diberlakukan seperti anak kecil, karena metode ini dilengkapi dengan lagu anak-anak.

Dengan banyaknya waktu KBM dapat menjadikan santri mudah jenuh. Dan disinilah peran guru sangat menentukan untuk meghilangkan kejenuhan tersebut. $^{23}$

\section{Gambaran Umum Madrasah Miftahul Ulum}

23 Ahmad, dkk, Efektivitas Penerapan, 42-43

28 | Tarbiyatuna: Jurnal Pendidikan Islam; Volume 13, Nomor 1, Februari 2020 p-ISSN: 2085-6539; e-ISSN: 2242-4579 
Hingga awal abad ke-20, sistem pendidikan di pondok pesantren Sidogiri terbatas pada pengajian kitab kepada pengasuh. Pendidikan klasikal baru terbentuk pada era kepengasuhan KH. Abdul Djalil pada 14 Safar 1357 H. atau 15 April 1938 M. Dalam perkembangannya, pendidikan klasikal atau pendidikan madrasiyah ini menjadi perioritas kedua setelah mengaji kepada pengasuh.

Pemikiran ini didorong karea santri yang mondok di pondok pesantren sidogiri saat itu tidak semuanya bisa mengikuti pengajian kitab yang dibacakan langsung oleh pengasuh. Sebagian dari mereka harus diberi pendidikan dasar agar dapat mengikuti pengajian kitab kuning yang dibacakan oleh pengasuh tersebut. Oleh karena itu didirikanlah madrasah ibtidaiyah dengan nama madrasah miftahul ulum.

Seiring bertambahnya murid, secara bertahap madrasah miftahul ulum terus melakukan pengembangan dalam berbagai bidang. Saat ini, terdapat empat jenjang pendidikan klasikal, yaiutu Idadiyah (khusus santri baru), Ibtidaiyah, Tsanawiyah, dan Aliyah. Semua tingkatan tersebut memiliki target dan menejemen tersendiri. Materi pelajaran dan kurikulum pun disusun sesuai kemampuan murid.

Sejak tahun 1961 M, pondok pesantren Sidogiri sudah memiliki madrasah filial (madrasah ranting) yang tersebar di berbagai wilayah di Jawa Timur. Visinya yakni terwujudnya peserta didik yang aliman, amilan, mukblisan bi amalibi. Adapun Misinya antara lain:

1. Mewujudkan murid yang mempunyai wawasan keagamaan yang mendalam ala ahlussunah wal jamaah

2. Mewujudkan murid yang inivatif dan kreatif dalam menerapkan ilmu pengetahuan

3. Membiasakan perilaku dan amaliyah keagamaan yang berlandaskan al-Quran, Hadits, dan perilaku Salafus-shaleh

4. Mencetak murid yang mempunya kepekaan sosial dan budaya

5. Mewujudkan murid yang memiliki keteladanan bagi kemaslahatan umat.

Materi pelajaran di miftahul ulum adalah ilmu agama dengan menggunakan kitab-kitab karya ulama salaf sebagai materi utama. Di kelas-kelas tertentu, ilmu sosial dan eksak tetap diajarkan sebagai pendukung ilmu-ilmu agama.

Rekrutmen guru diambil dari santri senior lulusan aliyah, serta dari alumni pondok pesantren sidogiri yang masih bersedia berkhidmah. Beberapa diantaranya ada yang menjadi pengasuh pondok pesantren dan dosen di perguruan tinggi.

Sebagai bentuk pembelajaran untuk berhemat dan mengatur keuangan dengan baik, semua murid madrasah miftahul ulum diwajibkan menabung. Kegiatan menabung 
dilaksanakan pada setiap pekan (hari sabtu). Untuk murid tingkat idadiyah dan ibtidaiyah jumlam minimal tabungan Rp. 2.000/pekan, tingkat Tsanawiyah Rp. 5.000/pekan, dan Aliyah Rp. 7.000/pekan. Uang tabungan akan dibagikan kepada murid di akhir tahun pelajaran, atau bisa diminta menjelang liburan Maulid, sekedar biaya transportasi pulang.

Pengurus menargetkan jam kosong madrasah tidak lebih dari 1\% dan presensi guru tidak kurang dari 95\%. Hal ini diupayakan melalui pengawasan KBM, pembentukan guru piket, program komunikasi, dan motivasi guru, serta penghargaan terhadap guru yang dinilai memiliki kedisplinan tinggi.

Setiap bulan, pengurus menargetkan presensi murid tidak kurang dari 95\%. Untuk mencapai target tersebut pihak pimpinan madrasah melakuan upaya-upaya sebagi berikut:

1. Program bimbingan dan konseling

2. Laporan murid disipliner kepada kepala daerah (asrama) setiap akhir pekan

3. Komunikasi dengan wali murid ${ }^{24}$

\section{Persiapan Implementasi Metode Al-Miftah Lil Ulum}

Adapun dalam persiapan implementasi metode Al-Miftah Lil Ulum dalam pembelajaran kitab kuning yang dilakukan oleh pondok pesantren sidogiri adalah menyiapkan calon guru yang akan mengajar Al-Miftah Lil Ulum terlebih dahulu. Persiapan ini dilakukan dengan cara memberikan bimibingan kepada calon guru yang mengajar sebanyak 3 kali sehari selama 4 hari pada bulan ramadhan. Hal ini dilakukan untuk agar calon guru yang mengajar dapat mengetahui sistem dan konsep penyampaian materi dari kitab Al-Miftah Lil Ulum kepada calon murid/santri. Pada tahun 2018 ini ada 147 guru yang membimbing pembelajaran kitab kuning dengan metode Al-Miftah Lil Ulum.

Sedangkan persiapan yang dilakukan pondok sidogiri kepada murid yang mengikuti pembelajaran kitab kuning dengan menggunakan metode al-miftah adalah dengan memberikan tes terlebih dahulu. Pemeberian tes ini dimaksud untuk mengetahui dan menyeleksi para murid yang sudah siap mengikuti pembelajaran kitab kuning dengan menggunakan metode Al-Miftah Lil Ulum. Sebab untuk mengikuti pembelajaran kitab kuning dengan menggunakan metode AlMiftah Lil Ulum ini setidaknya harus menguasai tulisan pego terlebih dahulu.

Bagi santri yang tidak lulus tes masih dapat mengikuti pembelajaran kitab kuning dengan menggunakan metode Al-Miftah Lil Ulum, akan tetapi diharuskan mengikuti kelas sifir dahulu.

\footnotetext{
24 Tamasya (Pasuruan: Sekretariat Pondok Pesantren Sidogiri, 1438H), 84-85

30 | Tarbiyatuna: Jurnal Pendidikan Islam; Volume 13, Nomor 1, Februari 2020 p-ISSN: 2085-6539; e-ISSN: 2242-4579
} 
Kelas sifir atau persiapan ini dimaksud untuk membekali santri dengan pelatihan baca tulis pego agar mudah mempelajari kitab kuning. Dan pada tahun 2018 ada sekitar 1.200 murid yang mengikuti program Al-Miftah Lil Ulum.

Adapun kurikulum dan format pembelajaran dari kelas I'dadiyah adalah sebagai berikut:

1. Format pembelajarannya diperkaya dengan lagu-lagu anak, kompetisi, tebak-tebakan, demonstrasi dan lain-lain.

2. Fokus pembelajaran kegiatan adalah upaya pembelajaran baca kitab efekti melalui metode, materi, dan guru khusus.

3. Santri yang mengikuti program al-miftah ditempatkan di asrama khusus untuk mendapatkan pengawasan khusus swlama 24 jam oleh kepala kamar dan guru pembina. Daerah J bagi santri umur 13 tahun ke bawah, daerah L khusus bagi santri usia diatas 13 tahun. Daerah M khusus santri idadiyah kelas takhasus yang sudah diwisuda. Dan daerah $\mathrm{N}$ untuk kelas taqrib yang pada tahun berikutnya belum lulus tes wisuda.

4. Tarbiyah Idadiyah memiliki 2 tingkatan, yakni Idadiyah I dan Idadiyah II. Idadiyah satu adalah tingkatan bagi santri yang baru. Materi Idadiyah I adalah kitab Al-Miftah Lil Ulum jilid I sampai IV, nadzam, tashrif, dan fathuk qorib.

5. Setiap jilid ditargetkan selesai dalam waktu minimal 25 hari, sehingga semua jilid bisa ditempuh dalam waktu 100 hari atau 3 bulan 10 hari. Sistem evaluasi Idadiyah I dilaksanakan setiap hari, tes tulis dan tes lisan yang dilaksanakan dua kali. Tes lisan pertama disebut tes lisan seleksi sedangkan tes lisan kedua disebut tes kenaikan jilid.

6. Murid yang sudah lulus tes 4 jilid sebelum pertengahan tahun, akan diwisuda telebih dahulu tanpa menunggu akhir tahun ajaran. Ada 68 murid idadiyah yang diwisuda pada bulan maulid, setelah diwisuda murid tersebut diharuskan menghapal fathul qorib.

7. Sedangkan Idadiyah II ada dua bagian, kelas takhassus dan taqrib. Kelas takhassus adalah santri yang telah diwisuda pada tahun sebelumnya. Materi pelajarannya adalah kitab fathul qorib, matan taqrib, tauhid -yang ditempuh selama 2 bulan- dan nadzam maqsud yang dipelajari setelah menghatamkan materi tauhid. Target kelas takhassus adalah santri yang bisa membaca fathul qorib meliputi lafal, makna, terjemah, dan pemahaman secara sempurna. Sistem evaluasi takhassus dilaksanakan setiap bulan, tes tulis meliputi fiqih dan sharraf, dan tes lisan membaca fathul qorib yang meliputi lafal, makna, kedudukan, terjemah, dan nadzam.

8. Untuk tahun berikutnya, santri takhassus bisa melanjutkan ke tingkat tsanawiyah dengan serangkaian tes yang dilaksanakan oleh Batartama. Sistem tes melanjutkan ke tingkat tsanawiyah adalah baca kitab fathul qorib awal sampai akhir, dan Tuhfatuth-Thullab sampai bab Syiyam. Untuk tes tulis adalah Alfiyah Ibnu Malik dan Balaghah. 
9. Sedangkan Idadiyah kelas taqrib adalah santri idadiyah yang tahun sebelumnya tidak lulus dalam tes wisuda. Materi pelajarannya sama dengan Idadiyah I. Sistem tes evaluasi dilaksanakan tiap bulan; tes tulis jilid I sampai IV dan tes lisan membaca fathul qorib meliputi lafal, kedudukan, dan nadzam.

\section{Pelaksanaan Metode Al-Miftah Lil Ulum dalam Pembelajaran Kitab Kuning}

Dalam garis-garis besar metode Al-Miftah Lil Ulum menyebutkan beberapa pola pikiran dan penggunaan secara global sebagai ciri khas dari metode Al-Miftah Lil Ulum yang merupakan dasar pelaksanaan Al-Miftah Lil Ulum itu sendiri. Diantara beberapa garis besar tersebut didapat data sebagai berikut:

1. Kitab al-miftah merupakan buku yang berjumlah 4 jilid dengan materi nahwu serta satu jilid sharaf disusun oleh badan tarbiyah wat taklim al-madrasy (BATARTAMA).

2. Buku ini sangat efisein untuk murid-murid baru yang sedang mempelajarai cara baca kitab klasik tanpa syakal (harakat) dengan syarat harus mampu menulis dan membaca arab pego terlebih dahulu. Karena dalam pelaksanaannya metode ini akan langsung diaplikasikan ke kitab fathul qorib dengan membaca lafad arab serta maknanya sekaligus.

3. Bagi santri yang belajar membaca kitab kuning dengan menggunakan metode ini diharuskan memiliki buku sendiri. Karena dalam buku tersebut memuat materi dengan desain aneka warna yang menarik.

4. Waktu kegiatan belajar mengajarnya adalah 8 jam perhari, yaitu
a. pagi jam 07.30 wis sd 13.10 wis
b. sore jam 17.00 wis sd 18.00 wis
c. malam jam 20.30 wis sd 23.45 wis

5. Sedangkan untuk belajar mengajarnya pondok sidogiri tidak melakukannya di dalam kelas. Karena sistemnya yang membuat para murid memiliki materi yang berbeda-beda. Dalam hal ini bukan ruang kelas yang dipakai, akan tetapi tingkatan jilid yang menentukan kelas dari masing-masing guru dan murid.

Adapun pelaksanaan implementasi metode Al-Miftah Lil Ulum dalam pembelajaran kitab kuning, pondok pesantren sidogiri menggunakan sebuah sistem yang jarang dipakai oleh lembaga pendidikan yang lainnya, yaitu dengan menggunakan sistem modul jilid dari Al-Miftah Lil Ulum itu sendiri.

Disamping garis-garis besar pelaksanaan al-miftah tersebut, pondok pesantren sidogiri menggunakan sebuah sistem yang unik dan menarik. Sistem ini dinamakan dengan sistem modul jilid bertingkat. Maksudnya kelompok belajar yang berjumlahkan 15-17 peserta didik berlomba- 
lomba menyelesaikan setiap jilid yang ada pada kitab Al-Miftah Lil Ulum. dalam hal ini jika murid dapat menyelesaikan tes yang diberikan oleh BATARTAMA mereka dapat melanjutkan ke jilid berikutnya tanpa harus menunggu temannya.

Untuk lebih jelasnya peneliti menggambarkan metode ini mirip dengan degradasi dalam permainan sepak bola atau olahraga yang lainnya. Berikut adalah gambaran dari sistem modul bertingkat diatas:

Gambar contoh sistem jilid bertingkat pada jilid 1
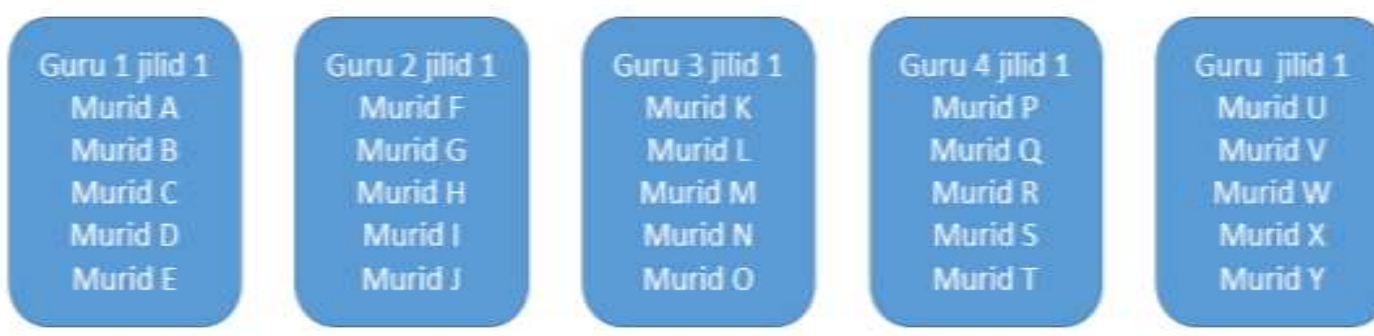

Gambar di atas merupakan penggambaran dari beberapa kelompok belajar dengan guru dan murid yang berbeda-beda. Guru di tandai dengan angka, dan murid ditandai dengan huruf yang mana sumua sedang membahas jilid 1 dari buku Al-Miftah Lil Ulum. Dari proses belajar mengajarnya guru memiliki beberapa murid yang akan dibimbing sampai dengan jilid 4 Al-Miftah Lil Ulum. akan tetapi guru tersebut tidak terus menerus mengajar murid yang sama. Akan tetapi ada Perolingan murid dalam sistem belajar mengajarnya. Perolingan ini terjadi ketika satu jilid dari buku Al-Miftah Lil Ulum terselesaikan dan murid berhasil lulus dari ujian tes kenaikan jilid yang diselenggarakan oleh Tim BATARTAMA.

Berikut adalah gambaran ketika sudah diselenggaran Tes kenaikan jilid oleh BATARTAMA :

Gambar contoh sistem jilid bertingkat pada kenaikan jilid 2
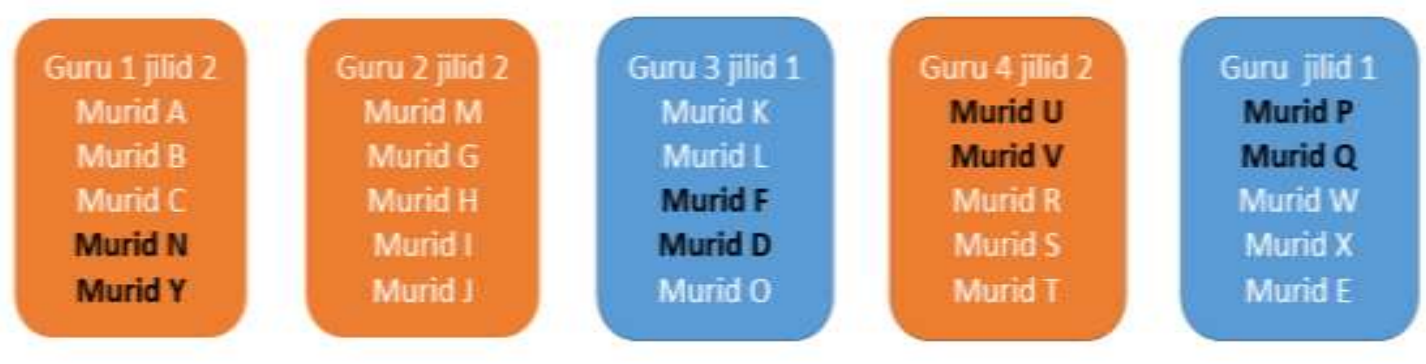
Gambar diatas menunjukan gamabaran dari hasil Evaluasi yang diselenggarakan oleh BATARTAMA diamana guru yang dapat meluluskan dengan jumlah murid terbanyak akan dapat melanjutkan mengajar Al-Miftah Lil Ulum Jilid ke-2. Sedangkan guru yang hanya meluluskan murid dengan jumlah terkecil akan tetap mengajar dijilid 1 dengan murid rolingan dari guru yang meluluskan dengan jumlah terbanyak dan begitu seterusnya sampai pada jilid 4 .

Bagi murid yang mesih belum bisa menyelesaikan tes jilid 1 dari materi Al Mifta Lil Ulum akan menetap pada jilid 1 dengan diroling pada guru yang meluluskan muridnya dengan jumlah terkecil. Murid yang mesih belum tuntas tersebut akan dibina dan dibimbing terus menerus sampai dia dapat menyelesaikan jilid 1 tersebut sebab mengingat begitu pentingnya materi pada setiap jilid Al-Miftah Lil Ulum dalam Mengkaji Kitab Kuning. Dan begitu seterusnya samapai dengan Jilid 4.

Jadi kesimpulan dari metode Modul Bertingkat tersebut mengajarkan bagi guru dan murid untuk lebih bersemangat dalam mempelajari setiap Jilid Al Mitah Lil Ulum.

Adapun dalam penyampaian materi dari tiap jilid guru dapat menggunakan beberapa macam metode pembelajaran kitab kuning. Diantaranya adalah metode ceramah, hafalan, sorogan, diskusi, dan demonstrasi. Metode tersebut digunakan guru dengan menyesuaikan kondisi murid ketika penyampaian materi.

Kitab kuning yang digunakan sebagai pengaplikasiannya adalah kitab Fathul Qorib karya Ibnu Qosim Al-Ghosi, sebuah kitab yang menjadi pembelajaran di pondok-pondok pesantren pada umumnya. Proses dalam pengaplikasiannya adalah dengan membaca perkata disertai dengan harakat-karakatnya sesuai dengan kaidah nahwu dan sharaf serta dengan menyebutkan dalil nadzam yang ada pada kitab Al-Miftah Lil Ulum.

\section{Hasil Metode Al-Miftah Lil Ulum dalam Pembelajaran Kitab Kuning}

Al-Miftah Lil Ulum yang merupakan salah satu metode cara cepat baca kitab kuning, maka hasil yang diperoleh dari implementasinya pun juga dapat mengantarkan murid-muridnya yang dapat menyelesaikan semua jilid dari kitab Al-Miftah Lil Ulum untuk dapat membaca kitab kuning kosongan.

Murid yang mengikuti metode Al-Miftah ini mampu membaca kitab kuning gundulan dengan memperhatikan kaidah-kaidah nahwu dan sharaf. Tidak hanya membaca saja, mereka juga mampu menyebutkan dalil-dalil dari susunan kalimatnya sesuai dengan nadzam dan keterangan yang ada di kitab Al-Miftah Lil Ulum.

Hal ini terbukti dengan adanya bahtsu masail yang merupakan sebuah forum musyawarah yang membahas sebuah masalah agama yang bersifat aktual yang berhubungan dengan kehidupan bermasyarakat dengan menggunakan jawaban yang mengacu pada kitab-kitab klasik maupun kitab 
kontemporer dalam menggali jawabannya. Forum bahtsu masail tersebut diselenggarakan untuk para murid idadiyah. Tentu hal ini tidaklah mudah bagi murid yang masih belum dapat mengusai gramatika arab yang membutuhkan pemahaman dari kitab nahwu dan sharaf. Disamping bahtsul masail yang diadakan oleh lembaga, pada akhir tahun murid Idadiyah juga dites publik pada saat wisuda Al-Miftah Lil Ulum.

\section{Kesimpulan}

Secara prinsip, implementasi metode apapun berhasil dan tidaknya jika dapat diukur antara sebelum dan sesudah dilaksanakan. Penelitian ini tidak untuk mengukur akurasi itu. Kesimpulan bersifat fenomenologis, yakni mendeskripsikan hasil observasi dan penelitian saja, tanpa mendiskusikannya dengan banyak terminologi dan teori lain. Sebelum metode al-Miftah dalam pembelajaran kitab kuning di pondok pesantren Sidogiri pasuruan dilaksanakan calon guru yang akan mengajar murid idadiyah yang menggunakan metode Al-Miftah Lil Ulum dipersiapkan pada bulan Ramadhan selama 4 kali dalam kurun waktu 3 nsampai 4 hari yang dipimpin langsung oleh pimpinan idadiyah. Sedangkan persiapan implementasi untuk para murid yang akan mengikuti kegiatan belajar mengajar dengan menggunakan metode Al-Miftah Lil Ulum akan diseleksi terlebih dahulu, karena murid yang dapat mengikuti kegiatan KBM dengan menggunakan metode Al-Miftah Lil Ulum setidaknya harus dapat membaca dan menulis tulisan arab pego terlebih dahulu. Dengan menggunakan metode Al-Miftah Lil Ulum para murid dapat membaca kitab kuning gundulan dalam kurun waktu kurang dari 1 tahun pelajaran. Hal ini dapat dibuktikan dengan adanya tes publik yang dilaksanakan pada saat wisuda al-miftah lil ulum dan juga Bahtsul Masail yang diselenggarakan oleh Batartama untuk murid-murid Idadiyah.

\section{Referensi}

Ahmad, dkk. Efektivitas Penerapan Metode Al-Miftah Dalam Meningkatkan Kemampuan Membaca Kitab Kuning Bagi Santri Baru Di Pondok. Pesantren Syaichona Moh. Cholil Bangkalan Madura.

Creswell, John W. Penelilitian Kualitatif \&Desain Riset. terj. Lintang Lazuardi

Dhofier, Zamakhsyari. 2015. Tradisi Pesantren. Jakarta: LP3ES.

Dimyati dan Mudjiono. 1999. Belajar dan Pembelajaran. Jakarta: Rineka Cipta.

Emzir. 2016. Metodeologi Penelitian Kualitatif: Analisis Data. Jakarta: Rajawali Pers.

Ismail. 2008. Strategi Pembelajaran Agama Islam Berbasis Paikem. Semarang: Rasail.

Mathusu. 1994. Dinamika Sistem Pendidikan Pesantren : Suatu Kajian Tentang Unsur Dan Nilai Sistem Pendidikan Pesantren. Jakarta : INIS.

Muhammad Bin Alwy. Mafahim Yajibu An Tushohhah. Surabaya: Ma'had Ad-Diinii As-Salafy.

Poerwadarminta, W.J.S. 1994. Kamus Besar Bahasa Indonesia. Jakarta: Balai Pustaka. 
Pondok Pesantren Sidogiri, Mari Kembalikan Gairah Baca Kitab di Bumi Nusantara Bersama Al-Miftah Lil Ulum, (sidogiri.net diakses pada tanggal 20 Pebruari 2018 pukul 01.23)

Tamasya. 1438H. Satu Mimpi Satu Barisan. Pasuruan: Sekretariat Pondok Pesantren Sidogiri.

Yazid, Abu, dkk. 2018. Paradigma Baru Pesantren Menuju Pendidikan Islam Transformatif. Yogyakarta : IRCiSoD 